ENGINEERING CHANGE NOTICE

\section{il}

1. ECN 629418

Page 1 of 2 Proj.

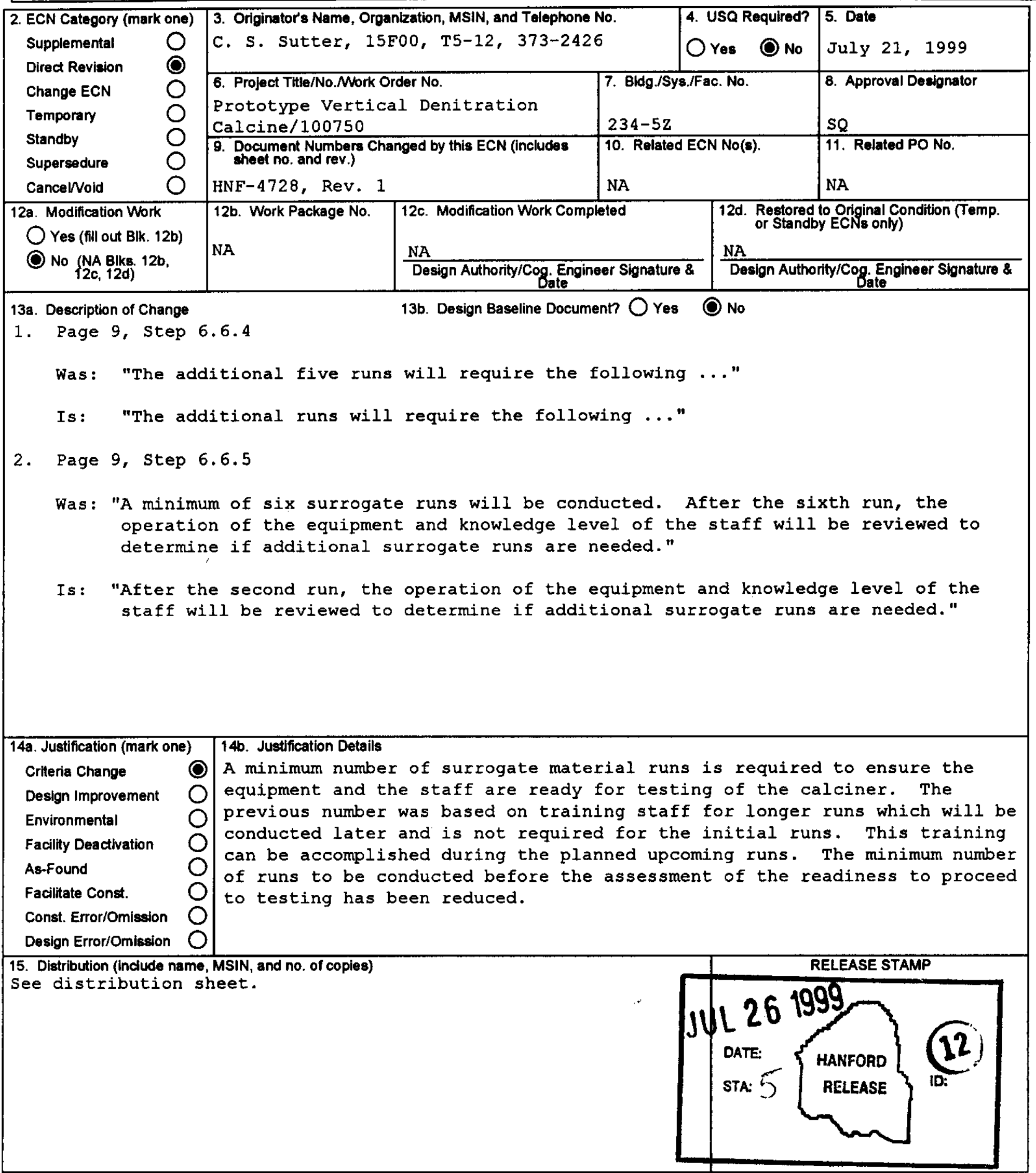




\section{ENGINEERING CHANGE NOTICE}

Page 2 of 22

16. Design Verification Required

OYes

O No
17. Cost Impact

ENGINEERING

Additional

$\$$ NA

Savings $O s$

\section{CONSTRUCTION}

Additional $O \& \underline{\mathrm{AN}}$

Savings $O \$$
1. ECN (use no. from pg. 1)

629418

18. Schodule Impact (days)

Improvement $\mathrm{O}$

Delay

19. Change Impact Review: Indicate the related documents (other than the engineering documents identified on Side 1) that will be affected by the change described in Block 13. Enter the affected document number in Block 20.

$\begin{array}{llll}\text { SDD/DD } & \square & \text { Seismic/Stress Analysis } & \square \\ \text { Functional Design Criteria } & \square & \text { Stress/Design Report } & \square \\ \text { Operating Specification } & \square & \text { Interface Control Drawing } & \square \\ \text { Criticality Specification } & \square & \text { Calibration Procedure } & \square \\ \text { Conceptual Design Report } & \square & \text { installation Procedure } & \square \\ \text { Equipment Spec. } & \square & \text { Maintenance Procedure } & \square \\ \text { Const. Spec. } & \square & \text { Engineering Procedure } & \square \\ \text { Procurement Spec. } & \square & \text { Operating Instruction } & \square \\ \text { Vendor Information } & \square & \text { Operating Procedure } & \square \\ \text { OM Manual } & \square & \text { Operational Safety Requirement } & \square \\ \text { FSAR/SAR } & \square & \text { IEFD Drawing } & \square \\ \text { Safety Equipment List } & \square & \text { Cell Arrangement Drawing } & \square \\ \text { Radiation Work Permit } & \square & \text { Essential Material Specification } & \square \\ \text { Environmental Impact Statement } & \square & \text { Fac. Proc. Samp. Schedule } & \square \\ \text { Environmental Report } & \square & \text { Inspection Plan } & \square \\ \text { Environmental Permit } & \square & \text { Inventory Adjustment Request } & \square\end{array}$

Tank Calibration Manual Health Physics Procedure Spares Multiple Unit Listing Test Procedures/Specification Component Index ASME Coded Item Human Factor Conelderation Computer Soltware Electric Circuit Schedule ICRS Procedure

Process Control Manual/Plan Process Flow Chart Purchase Requisition Tickler File NA

20. Other Affected Documents: (NOTE: Documents listed below will not be revised by this ECN.) Signatures below indicate that the signing organization has been notified of other affected documents listed below. Document Number/Revision

NA
Document Number/Revision

Document Number/Revision

NA

\section{Signature}

Date

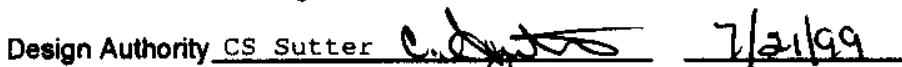
Cog. Eng. JA compton frowle Q (mator $7-21-99$

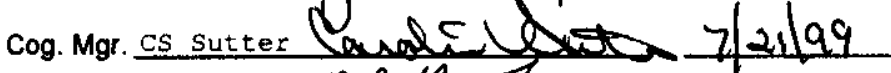

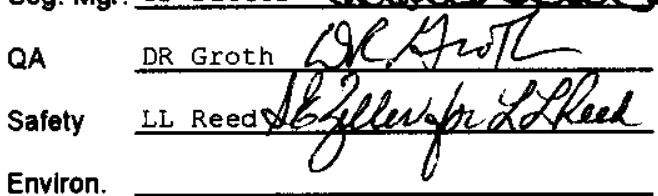

Other

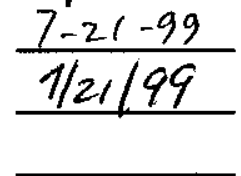

Design Agent

PE

QA

Safety

Design

Environ.

Other

\section{DEPARTMENT OF ENERGY}

Signature or a Control Number that tracks the Approval Signature

ADDITIONAL 


\title{
Restart Plan for the Prototype Vertical Denitration Calciner
}

\author{
C. S. Sutter \\ P. O. Box 1200 MS T5-12 \\ Richland, WA 99352 \\ U.S. Department of Energy Contract DE-AC06-86RL13200 \\ EDT/ECN: $629418 \quad$ UC: \\ Org Code: 15F00 Change Code: 100750 \\ B\&R Code: \\ Total Pages: 2021

$$
\text { dp } 7 / 26 / 99
$$

Key Words:

plutonium, plutonium nitrate, prototype calciner, restart, restart plan, direct denitration, vertical calciner, readiness

Abstract:

Testing activities on the Prototype Vertical Denitration Calciner at PFP were suspended in January 1997 due to the hold on fissile material handling in the facility. The Restart Plan will govern the transition of the test program from the completion of the activity based startup review; through equipment checkout and surrogate material runs; to resumption of the testing program and transition to unrestricted testing

TRADEMARK DISCLAIMER, Reference herein to any specific commercial product, process, or service by trade name, trademark, manufacturer, or otherwise, does not necesearily conetitute or imply its endoreement, recommendation, or favoring by the United States Government or any agency thereof or its contractors or subcontractors.

Printed in the United States of America. To obtain copies of this document, contact: Document Control Services, P.O. Box 950, Mallstop H6-08, Richland WA 99352, Phone (509) 372-2420; Fax (509) 376-4989.
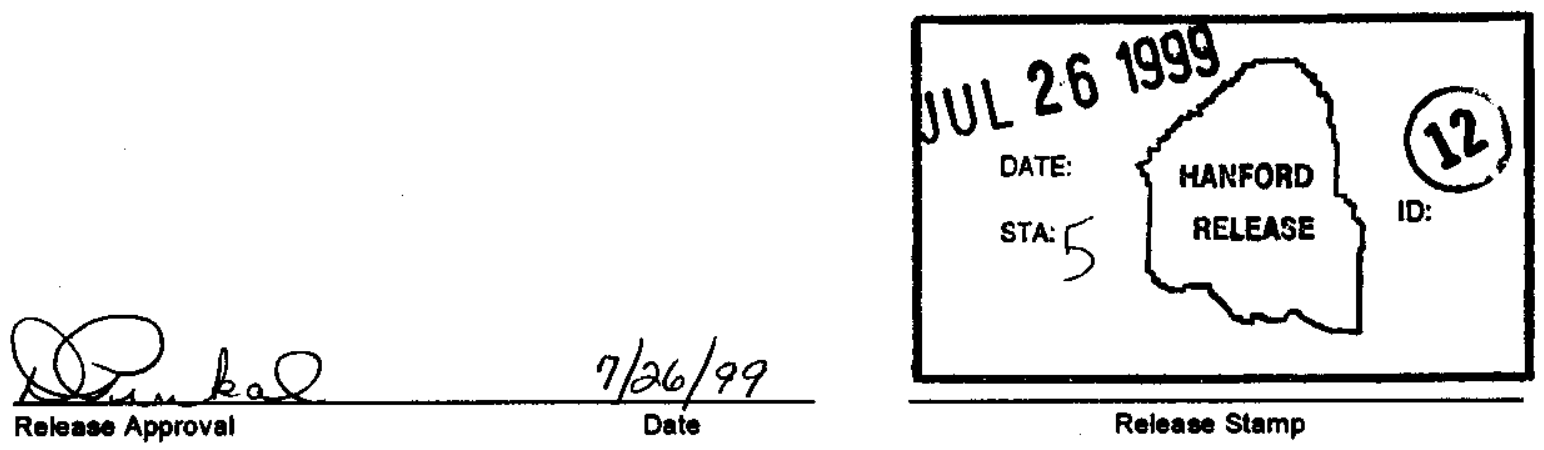

Release Stamp

\section{Approved For Public Release}




\section{DISTRIBUTION SHEET}

To

Distribution

Project Title/Work Order

HNF-4728, "Restart Plan for the Prototype Vertical Denitration

Calciner"

Name

Anderson, P. R.

Carey, J. R.

Compton, J.A.

Crawford, F. R.

Donovan, T. K.

Heineman, R. E.

Redekopp, R. D.

Reed, I. L.

Sato, P. K.

Shaffer, R. D.

Sinclair, J. C.

sutter, C. S.

Zeller, S. E.

Central Files

DOE-RL Reading Room
From

C. S. sutter

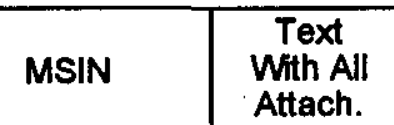

T5-12

T5-48

T5-12

T5-50

T5-02

T5-50

$\mathrm{T} 5-15$

T5-57

T5-50

T5-50

T5-50

T5-12

T4-15

B1-07

H2-53

\begin{tabular}{|l}
\hline$x$ \\
\hline$x$ \\
\hline$x$ \\
\hline$x$ \\
\hline$x$ \\
\hline$x$ \\
\hline$x$ \\
\hline$x$ \\
\hline$x$ \\
\hline$x$ \\
\hline$x$ \\
\hline$x$ \\
\hline$x$ \\
\hline$x$ \\
\hline
\end{tabular}

Page 1 of 1

Date $07 / 21 / 99$

EDT No. NA

ECN No. 629418

\begin{tabular}{|c|c|c|}
\hline Text & $\begin{array}{l}\text { Attach./ } \\
\text { Appendix } \\
\text { Only }\end{array}$ & $\begin{array}{c}\text { EDT/ECN } \\
\text { Only }\end{array}$ \\
\hline
\end{tabular}

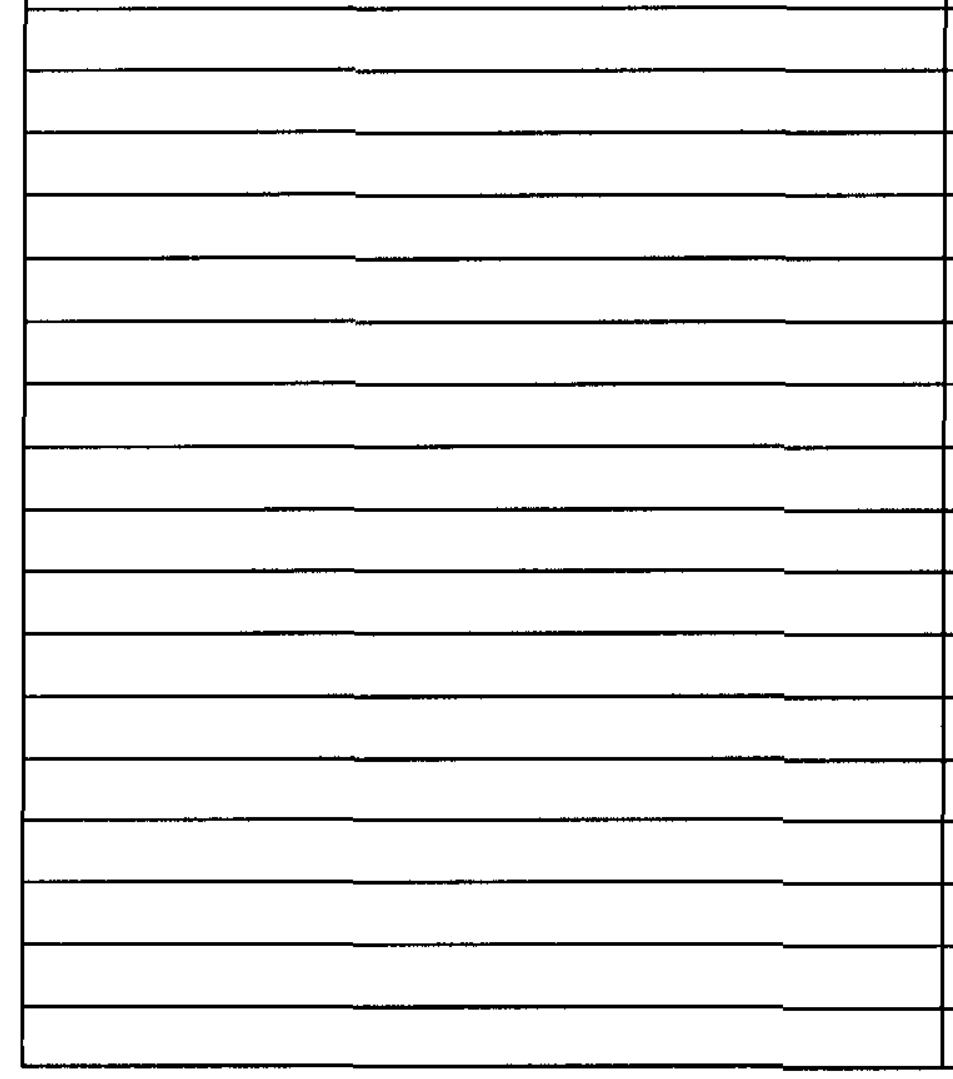

\begin{tabular}{|l|l|}
\hline $\mathrm{H} 2-53$ & $\mathrm{X}$ \\
\hline & \\
\hline
\end{tabular}


RECORD OF REVISION

\section{(2) Title}

Restart Plan for the Prototype Vertical Denitration Calciner

\section{Change Control Record}

(3) Revision

$1 \quad$ ECN 629419 - Revised checklist to address readiness review items.

$\mathbf{R S}^{2}$
(4) Description of Change - Replace, Add, and Delete Pages

ECN 629418 - Reduced miminum number of surrogate runs from six to two.
Authorized for Releace

\begin{tabular}{l|ll}
\hline (5) Cog. Engr. & (6) Cog. Mgr. Date \\
\hline
\end{tabular}

JA Compton CS Sutter

JA Compton CS Sutter

JA comptor/2 pes sutter 312699 Conatar 


\section{HNF-4728}

\section{RESTART PLAN FOR THE PROTOTYPE VERTICAL DENITRATION CALCINER}

JULY 21, 1999

Revision 2

This Document is UNCIASSIFIED.

Work Performexi unier this reauirement is LULCLFSEIFIED

-COPHIDENTIA

— SECRET

woßaitur

Signature AUTHORIZED CLASSIFIER 


\section{APPROVALS:}

F. R. Crawford, Sr.|Director

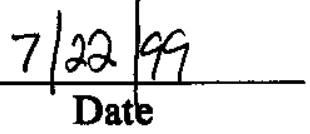

Plutonium Finishing Plant Project

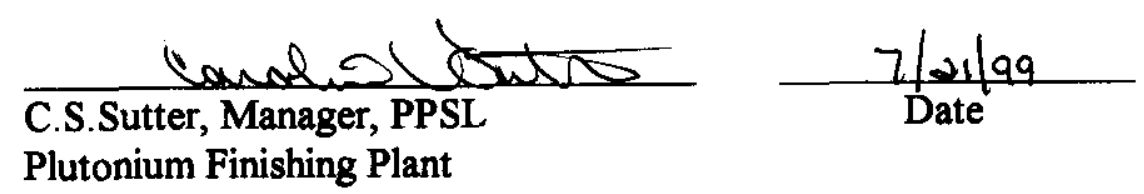


Restart Plan for the Prototype Vertical

Denitration Calciner
July 21,1999

HNF-4728, Revision 2

Page 3 of 19

\section{TABLE OF CONTENTS}

1.0 OBJECTIVE . .4

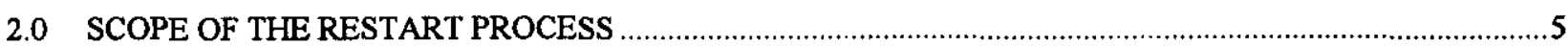

4.0 ORGANIZATION/ RESPONSIBILITIES

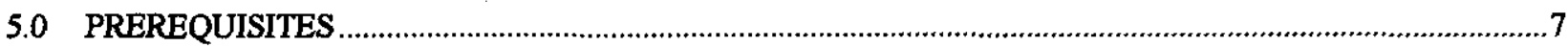

6.0 RESTART OF PROTOTYPE VERTICAL DENITRATION CALCINER ACTIVITIES ……..............................

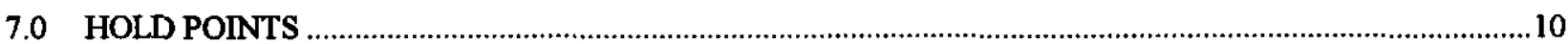

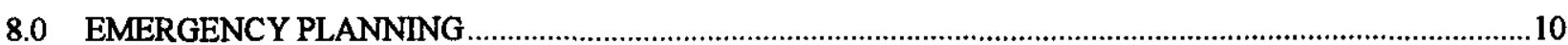

9.0 DOCUMENT RETENTION

10.0 REFERENCES

\section{LIST OF ATTACHMENTS}

Attachment A: $\quad$ Prototype Vertical Denitration Calciner Procedures

Attachment B: $\quad$ Approval checklist for the Restart of the Prototype Vertical Denitration Calciner 
Restart Plan for the Prototype Vertical

Denitration Calciner
HNF-4728, Revision 2

Page 4 of 19

\subsection{OBJECTIVE}

Efforts are underway to restart the testing program for the prototype Vertical Denitration Calciner (PVDC) in the Plutonium Process Support Laboratories (PPSL). The PVDC test program was intended to confirm and identify improvements to the design and operational parameters of the production VDC for the conversion of plutonium bearing solution to stabilized, storable solids. The PVDC was previously operated in 1995 and 1996. In January 1997, testing activities were suspended due to the restriction on fissile material handling activities in the Plutonium Finishing Plant (PFP). The approval to continue the test activities will require an Activity Based Startup Review. The completion of the plan will provide a readiness determination basis to authorize safe resumption of testing activities. Upon the completion of the review, the controlled restart of the PVDC will be conducted in accordance with this Restart Plan.

The PVDC test activities will be conducted to evaluate previous modifications; productivity and reliability motivated, mechanical modifications, and execute the Test Plan. The performance of equipment modifications to be tested during the activities includes a new agitator and feed pump. The Restart Plan will govern the transition of the test program from the completion of the activity based startup review; through equipment checkout and surrogate material runs; to resumption of the testing program with plutonium bearing solutions; and the final transition to unrestricted testing. The plan provides a phased approach that bridges the activities between the approval to restart and the return to test activities.

After receiving the approval to restart given by the startup approval authority, equipment checkout will commence in accordance with this plan. Activities will include the use of various procedures identified in Attachment A. After the completion of each phase, the readiness of the PPSL to commence to the next phase with the PVDC will be confirmed. Approval to start each phase of the restart plan will be given by the Sr. Director after verification of readiness.

This Restart Plan provides compensatory measures such as oversight and hold points within the following objectives:

1.1 To ensure that activities are conducted in a safe manner.

1.2 To provide supplemental support to the Plutonium Process Support Laboratories (PPSL) during the initial startup of the Prototype Vertical Denitration Calciner until the commencement of testing.

1.3 To ensure that testing can be conducted in a manner that meets BWHC, FDH and DOE expectations associated with the principles of integrated safety management. 


\subsection{SCOPE OF THE RESTART PROCESS}

In addition to the PVDC itself, the following describes the supporting equipment. The prototype vertical denitration calciner, scrubber system, feed injection equipment, containers, tanks, ceramic filters, associated valves and metering pumps are located in glovebox 188-1. External equipment includes the chiller system for the scrubber chilled water, caustic supply and delivery pump, and the control panel.

\subsection{DEFINITIONS}

3.0 Cognizant engineer - The engineer designated by the PPSL Manager to be responsible for the development and conduct of the PVDC test program. The Cognizant Engineer is the subject matter expert for all calciner related topics and will complete Attachment B in his areas of responsibilities.

3.1 Nitric Acid Runs - Process test runs conducted with non-fissile surrogate material (nitric acid) prior to the introduction of activities with fissile material for purposes of training personnel, and validating of equipment changes.

3.2 Compensatory Actions - Those temporary provisions that have been implemented in addition to normal practices for the purpose of ensuring safe operations until additional operating experience is achieved.

3.3 Manager PPSL - The senior PFP manager in charge of the PPSL. The Manager PPSL is the owner of this plan. The Manager PPSL reports to the Sr. Director PFP Project.

3.4 Plutonium Process Support Laboratories (PPSL) - This organization conducts development activities to develop new processes, refine process flow sheets and resolve operational problems. The PVDC test program is one such activity.

3.5 Test Plan for Radioactive Testing of a Vertical Direct Denitration Calciner (Test Plan) - The documentation that governs the test program for the PVDC. The Test Plan, for the PVDC test program is HNF-SD-CP-TP-088, (reference 10.2). The Test Plan includes items such as the description of the testing activities, expected results, test procedure and oversight requirements.

3.6 Restart Checklist - A checklist of items to be verified prior to commencing each operational phase.

3.7 Restart Plan (Plan) - The restart plan governs the transition of the Prototype 
Vertical Denitration Calciner from the completion of the activity based startup review, through equipment checkout and surrogate runs, resumption of testing with plutonium bearing solution to unrestricted testing.

3.8 Senior Director, Plutonium Finishing Plant Project (Sr. Director) - The overall senior manager responsible for the operation of the Plutonium Finishing Plant.

3.9 Senior Supervisory Watch (SSW) - PFP managers selected by the PFP Plant Director of Operations to represent senior PFP management in observing and reviewing the conduct of various plant activities. The SSW provides an ongoing management presence, which provides real-time feedback on the state of the plant, personnel training, appropriateness of actions, safety, housekeeping, etc.

\subsection{ORGANIZATION/ RESPONSIBILITIES}

\subsection{PPSL}

4.1.1 The PPSL organization shall consist of the PPSL group. This group includes engineers, scientists, and technicians on one full time day shift, and the Manager of PPSL.

4.1.2 Responsibilities within PPSL are assigned as follows:

4.1.2.1 The Manager, PPSL shall be responsible under the Sr. Director of the PFP Project for the execution of all testing activities. This will include, but not limited to, coordination with the cognizant engineer, Criticality Safety Representative, and ESH\&QA Manager to ensure that all process activities are completed in a timely, safe manner.

4.1.2.2 The Cognizant Engineer shall have the responsibility to execute the test activities contained in the Test Plan.

\subsection{Management oversight}

4.2.1 The Manager, PPSL is the overall coordinator of the Restart process. These responsibilities include the oversight of testing associated with the execution of this Plan. 
4.2.2 The SSW is responsible to the PFP Director of Operations to provide management oversight of the execution of the restart activities as described in section 6.0 .

\subsection{PPSL Support}

4.3.1. PPSL support personnel will be identified as required. When no special requirements are established, then PPSL support will be as required for normal activities. PPSL support personnel include the Building Emergency Director, maintenance, radiological controls, solid waste personnel, vault operations personnel, surveillance personnel, etc, as needed.

4.3.2. The responsibilities for PPSL support personnel shall be as directed by PFP procedures and test plans.

\subsection{PREREQUISITES}

5.1 Commencement of each phase shall not be initiated until all of the following prerequisites have been completed.

5.1.1 All prerequisites have been completed and signed off as required by Attachment B. The Manager, PPSL has reviewed the results, and recommended to the Sr. Director to continue into the next phase.

5.1.2 Approval for the commencement of the prototype VDC has been provided by the Sr. Director, and the Manager, PPSL has directed the start of the phase.

\subsection{RESTART OF PROTOTYPE VERTICAL DENITRATION CALCINER ACTIVITIES}

6.1 There are three phases for the restart. The first phase is equipment checkout. The second phase is surrogate material runs. The third phase is plutonium solution runs.

6.2 Each phase will be conducted with appropriate involvement of the FDH mentors, facility management, and SSW oversight. SSW oversight will be used during equipment checkout as determined by the PFP Director of Operations. During surrogate runs, SSW oversight will be conducted on a portion of each run. 
6.3 Operation of the calciner will require conformance to the Test Plan. The process for modifying the Test Plan will be provided in the Test Plan and will conform to FSP-PFP-0887.

6.4 Each phase will require the completion of a checklist, concurrence by the Manager, PPSL and approval by the Sr. Director prior to executing the phase. The following are checklist topics contained in Attachment B.

Procedures are adequate and correct. Modifications from changes are incorporated.

Level of knowledge is adequate to move to the next phase.

Spare parts are adequate to move to the next phase.

Safeguards and security requirements have been addressed for the next phase.

Radiological controls/equipment are adequate to move to the next phase.

Criticality systems are operational.

Seismic detection and shutdown systems are tested and are operational.

Verification that glovebox conditions meet the CPS requirements for planned operations.

Instrumentation is calibrated.

Equipment repairs/modifications are complete.

Training and qualifications are complete and current.

Required corrective actions are complete.

Operations support is adequate.

\subsection{Phase 1:}

6.5.1 The objective of the equipment checkout (phase 1) is to conduct controlled testing to confirm that the new agitator and liquid feed pump will function satisfactorily with surrogate materials.

6.5.2 This Phase 1 equipment checkout will be conducted primarily by the qualified personnel, and will be used to provide OJT for personnel in training.

6.5.3 The PFP Director of Operations will be notified of intent to conduct equipment checkout and the planned operations. The PFP Director of Operations shall require the SSW for the day to periodically monitor the equipment checkout activities.

6.5.4 When the cognizant engineer determines the equipment is ready for 
surrogate material runs, the Phase 1 checklist will be completed to determine readiness to proceed to Phase 2.

\subsection{Phase 2}

6.6.1 The objective of the surrogate runs (phase 2) is to provide the OJT training to new personnel required by the qualification process and conduct further testing of the equipment.

6.6.2 This phase 2 surrogate runs will be conducted by the qualified personnel, but will include extensive OJT for new personnel. This phase will also be utilized to ensure that any changes from the prior phase have been properly implemented into the procedures and test plan.

6.6.3 The test plan shall be open and in use during Phase 2. The steps shall be performed as written.

6.6.4 The PFP Director of Operations will be notified of intent to conduct a surrogate nun. The PFP Director of Operations shall require full time SSW coverage for the first surrogate run. The additional runs will require the following minimum SSW coverage: during the prejob, startup of the calciner and initiation of the transfer of the feed to the calciner.

6.6.5 After the second run, the operation of the equipment and knowledge level of the staff will be reviewed to determine if additional surrogate runs are needed.

6.6.6 When 6.6.5 has been met, the Phase 2 checklist will be completed to determine readiness to proceed to Phase 3.

\subsection{Phase 3:}

6.7.1 The objective of the fissile material runs is to test the various types of solutions to evaluate technical considerations that might have an impact in processing scenarios.

6.7.2 This phase will be conducted by the qualified personnel, and will include extensive OJT for new personnel. This phase will also be utilized to ensure that any changes from the prior phase have been properly implemented into the procedures and test plan. 
6.7.3 The test plan shall be open and in use during Phase 3. The steps shall be performed as written.

6.7.4 The PFP Director of Operations will be notified of intent to conduct a fissile material nun. The PFP Director of Operations shall require full time SSW coverage for the first fissile material run. The second run will require the following minimum SSW coverage: during the prejob, startup of the calciner, initiation of transfer of the feed to the calciner, and product loadout.

6.7.5 After completion of two runs, the Phase 3 checklist will be completed to determine readiness to complete the restart plan and resume unrestricted operations.

\subsection{HOLD POINTS}

7.1 Four hold Points have been established to ensure that critical activities are reviewed prior to starting a new activity phase. Prototype Vertical Denitration Calciner activities shall not proceed past a hold point until formal approval from the PFP Sr. Director has been provided. The Hold Points are identified in Attachment B and are listed below.

Hold Point \#1: $\quad$ All pre-start checklist items are complete and the Sr. Director has directed the commencement of Phase 1 equipment checkout test runs.

Hold Point \#2: $\quad$ All phase 1 test activities, and checklist items are complete and the Sr. Director has directed the commencement of Phase 2 Surrogate test runs.

Hold Point \#3: $\quad$ All Phase 2 surrogate test run activities and checklist items are complete and the Sr. Director has directed the commencement of fissile material test runs under the restart plan.

Hold Point \#4

All restart plan activities are complete, and the Sr. Director has directed the commencement of unrestricted test activities.

\subsection{EMERGENCY PLANNING}

Equipment checkout (phase 1) and surrogate material runs (phase 2) will be conducted on day shift. As a result, normal PFP emergency plans will be in effect during all prototype VDC 
activities, unless the Manager, PPSL deems it necessary to increase the emergency response posture.

Each fissile material run (Phase 3) and unrestricted operation of the prototype calciner will typically be conducted over a 12-16 hour period. The off shift emergency response support for fissile material runs will be assessed prior to Phase 3.

\subsection{DOCUMENT RETENTION}

The Manager, PPSL shall compile and store all completed checksheets, and supporting documents. They shall be processed as quality documents in accordance with current procedures.

\subsection{REFERENCES}

10.1 "Activity Based Startup Review Plan", HNF-4522.

10.2 "Test Plan for radioactive Testing of the Vertical Direct Denitration Calciner", HNF-SD-CP-TP-088 


\section{ATTACHMENT A}

PROTOTYPE VERTICAL DENITRATION CALCINER PROCEDURES

\begin{tabular}{|l|l|l|}
\hline ITEM & $\begin{array}{l}\text { PROCEDURE } \\
\text { NUMBER }\end{array}$ & TITLE \\
\hline 1 & ZP-100-001 & Seal Out PPSL Gloveboxes \\
\hline 2 & ZP-100-003 & Use of Plutonium Process Support Laboratories Airlock \\
\hline 3 & ZP-100-004 & Label PPSL Nuclear Materials \\
\hline 4 & ZP-100-008 & Apply Pressure Sensitive Seals in PPSL \\
\hline 5 & ZP-100-009 & Change PPSL Glovebox Gloves and Bags \\
\hline 6 & ZP-100-012 & Inspect PPSL Gloves \\
\hline 7 & ZP-100-015 & $\begin{array}{l}\text { Operate PPSL Can Sealer and Inspect double Seam on Seam Sealed } \\
\text { Cans }\end{array}$ \\
\hline 8 & ZP-100-017 & Apply and Remove Cup/Wire Seals in PPSL \\
\hline 9 & ZSP-002 & Move Special Nuclear Material \\
\hline 10 & HNF-CP-TP-088 & $\begin{array}{l}\text { Test Plan for Radioactive Testing of Vertical Direct Denitration } \\
\text { Calciner }\end{array}$ \\
\hline 11 & ZCR-001 & Continuous Air Monitor Alarm \\
\hline 12 & ZCR-012 & Breached Glove \\
\hline
\end{tabular}



ATTACHMENT B

APPROVAL CHECKLIST FOR THE RESTART OF THE PROTOTYPE VERTICAL DENITRATION CALCINER

\begin{tabular}{|c|c|c|c|c|}
\hline ITEM \# & DESCRIPTION & REMARKS/REQUIREMENTS & $\begin{array}{l}\text { DATE } \\
\text { COMPLETE }\end{array}$ & SIGNATURE \\
\hline \multicolumn{5}{|c|}{ PRE-OPERATIONAL /EQUIPMENT CHECKOUT RUN CHECKLIST } \\
\hline $\begin{array}{l}\text { Hold } \\
\text { Point } \\
\# 1\end{array}$ & $\begin{array}{l}\text { All pre-start items from the activity based } \\
\text { startup plan (HNF-4522) are complete and } \\
\text { the Sr. Director has directed the } \\
\text { commencement of Phase } 1 \text { equipment } \\
\text { checkout Runs. }\end{array}$ & $\begin{array}{l}\text { Attach copy of restart authorization from Sr. } \\
\text { Director. }\end{array}$ & & F. R. Crawford \\
\hline \multicolumn{5}{|c|}{ READINESS TO PROCEED TO PHASE 2 CHECKLIST } \\
\hline 1 & $\begin{array}{l}\text { Procedures are adequate and correct. } \\
\text { Modifications from changes are } \\
\text { incorporated. Functional testing of the } \\
\text { Room } 188 \text { safety shower has been } \\
\text { completed per ZP-100-013, "Test Safety } \\
\text { Showers and Eye Wash Fountain in PPSL" }\end{array}$ & $\begin{array}{l}\text { Provide list of applicable procedures and } \\
\text { verification process used. }\end{array}$ & & COG ENG \\
\hline 2 & $\begin{array}{l}\text { Level of knowledge is adequate to move } \\
\text { to the next phase. }\end{array}$ & Provide documentation of verification process & & COG ENG \\
\hline 3 & $\begin{array}{l}\text { Spare parts and preventive maintenance } \\
\text { are adequate to move to the next phase. }\end{array}$ & $\begin{array}{l}\text { Provide list of parts/PMs and verification of } \\
\text { process used. }\end{array}$ & & COG ENG \\
\hline
\end{tabular}




\begin{tabular}{|c|c|c|c|}
\hline \multicolumn{2}{|c|}{$\begin{array}{l}\text { Restart Plan for the Prototype Vertical } \\
\text { Denitration Calciner }\end{array}$} & $\begin{array}{r}\text { HNF-4728, Revision } 2 \\
\text { Page } 14 \text { of } 19 \\
\end{array}$ & \\
\hline 4 & $\begin{array}{l}\text { Safeguards and security requirements have } \\
\text { been addressed for the next phase. }\end{array}$ & $\begin{array}{l}\text { Provide documentation of verification process } \\
\text { used. }\end{array}$ & COG ENG \\
\hline 5 & $\begin{array}{l}\text { Radiological controls/equipment are } \\
\text { adequate to move to the next phase. }\end{array}$ & $\begin{array}{l}\text { Provide documentation of verification process } \\
\text { used. }\end{array}$ & COG ENG \\
\hline 6 & Criticality systems are operational. & $\begin{array}{l}\text { Provide documentation of verification process } \\
\text { used. }\end{array}$ & COG ENG \\
\hline 7 & $\begin{array}{l}\text { Seismic detection and shutdown systems } \\
\text { are tested and are operational. }\end{array}$ & $\begin{array}{l}\text { Provide documentation of verification process } \\
\text { used. }\end{array}$ & COG ENG \\
\hline 8 & $\begin{array}{l}\text { Verification that glovebox conditions meet } \\
\text { the CPS requirements for planned } \\
\text { operations. }\end{array}$ & $\begin{array}{l}\text { Provide documentation of verification process } \\
\text { used. }\end{array}$ & COG ENG \\
\hline 9 & Instrumentation is calibrated. & $\begin{array}{l}\text { Provide documentation of verification process } \\
\text { used. }\end{array}$ & COG ENG \\
\hline 10 & $\begin{array}{l}\text { Equipment repairs/modifications are } \\
\text { complete. }\end{array}$ & $\begin{array}{l}\text { Provide list of any repairs/modifications and } \\
\text { provide documentation of verification. }\end{array}$ & COG ENG \\
\hline 11 & $\begin{array}{l}\text { Training and qualifications are complete } \\
\text { and current. }\end{array}$ & $\begin{array}{l}\text { Provide documentation of verification process } \\
\text { used. }\end{array}$ & COG ENG \\
\hline 12 & Required corrective actions are complete. & $\begin{array}{l}\text { Provide list of corrective actions and } \\
\text { documentation of verification process. }\end{array}$ & COG ENG \\
\hline
\end{tabular}




\begin{tabular}{|c|c|c|c|}
\hline \multicolumn{2}{|c|}{$\begin{array}{l}\text { Restart Plan for the Prototype Vertical } \\
\text { Denitration Calciner }\end{array}$} & $\begin{array}{r}\text { HNF-4728, Revision } 2 \\
\text { Page } 15 \text { of } 19 \\
\end{array}$ & \\
\hline 13 & Operations support is adequate. & $\begin{array}{l}\text { Provide list of needs and document verification } \\
\text { process. }\end{array}$ & COGENG \\
\hline 14 & $\begin{array}{l}\text { All equipment checkout runs are complete, } \\
\text { and the results satisfactory. The checklist } \\
\text { items for the surrogate test runs have been } \\
\text { reviewed for adequacy and completeness. } \\
\text { The movement to the next phase is } \\
\text { recommended }\end{array}$ & & PPSL Mgr. \\
\hline $\begin{array}{l}\text { Hold } \\
\text { Point } \\
\# 2\end{array}$ & $\begin{array}{l}\text { All equipment checkout Runs have been } \\
\text { successfully completed, and the Manager, } \\
\text { PPSL has recommended the } \\
\text { commencement of surrogate test runs. }\end{array}$ & $\begin{array}{l}\text { Verify that the documents supporting the } \\
\text { completion of equipment test runs, procedural } \\
\text { changes, etc have been completed, and the } \\
\text { process is ready to proceed to fissile material } \\
\text { activities. }\end{array}$ & $\overline{\text { F.R.Crawford }}$ \\
\hline \multicolumn{4}{|c|}{ READINESS TO PROCEED TO PHASE 3 CHECKLIST } \\
\hline 1 & $\begin{array}{l}\text { Procedures are adequate and correct. } \\
\text { Modifications from changes are } \\
\text { incorporated. }\end{array}$ & $\begin{array}{l}\text { Provide list of applicable procedures and } \\
\text { verification process used. }\end{array}$ & COG ENG \\
\hline 2 & $\begin{array}{l}\text { Level of knowledge is adequate to move } \\
\text { to the next phase. }\end{array}$ & Provide documentation of verification process & COG ENG \\
\hline 3 & $\begin{array}{l}\text { Spare parts and preventive maintenance } \\
\text { are adequate to move to the next phase. }\end{array}$ & $\begin{array}{l}\text { Provide list of parts/PMs and verification of } \\
\text { process used. }\end{array}$ & COG ENG \\
\hline 4 & $\begin{array}{l}\text { Safeguards and security requirements have } \\
\text { been addressed for the next phase. }\end{array}$ & $\begin{array}{l}\text { Provide documentation of verification process } \\
\text { used. }\end{array}$ & COGENG \\
\hline
\end{tabular}




\begin{tabular}{|c|c|c|c|}
\hline \multicolumn{2}{|c|}{$\begin{array}{l}\text { Restart Plan for the Prototype Vertical } \\
\text { Denitration Calciner }\end{array}$} & $\begin{array}{r}\text { HNF-4728, Revision } 2 \\
\text { Page } 16 \text { of } 19 \\
\end{array}$ & \\
\hline 5 & $\begin{array}{l}\text { Radiological controls/equipment are } \\
\text { adequate to move to the next phase. }\end{array}$ & $\begin{array}{l}\text { Provide documentation of verification process } \\
\text { used. }\end{array}$ & COG ENG \\
\hline 6 & $\begin{array}{l}\text { Criticality systems are operational and } \\
\text { ensure Criticality Prevention Specification } \\
\text { (CPS) posting "Room } 188 \text { Allowed } \\
\text { Storage Containers" is in place. } \\
\end{array}$ & $\begin{array}{l}\text { Provide documentation of verification process } \\
\text { used. }\end{array}$ & COG ENG \\
\hline 7 & $\begin{array}{l}\text { Seismic detection and shutdown systems } \\
\text { are tested and are operational. }\end{array}$ & $\begin{array}{l}\text { Provide documentation of verification process } \\
\text { used. }\end{array}$ & COG ENG \\
\hline 8 & $\begin{array}{l}\text { Verification that glovebox conditions meet } \\
\text { the CPS requirements for planned } \\
\text { operations. }\end{array}$ & $\begin{array}{l}\text { Provide documentation of verification process } \\
\text { used. }\end{array}$ & COG ENG \\
\hline 9 & Instrumentation is calibrated. & $\begin{array}{l}\text { Provide documentation of verification process } \\
\text { used. }\end{array}$ & COG ENG \\
\hline 10 & $\begin{array}{l}\text { Equipment repairs/modifications are } \\
\text { complete. }\end{array}$ & $\begin{array}{l}\text { Provide list of any repairs/modifications and } \\
\text { provide documentation of verification. }\end{array}$ & COG ENG \\
\hline 11 & $\begin{array}{l}\text { Training and qualifications are complete } \\
\text { and current. }\end{array}$ & $\begin{array}{l}\text { Provide documentation of verification process } \\
\text { used. }\end{array}$ & COG ENG \\
\hline 12 & Required corrective actions are complete. & $\begin{array}{l}\text { Provide list of corrective actions and } \\
\text { documentation of verification process. }\end{array}$ & COG ENG \\
\hline
\end{tabular}




\begin{tabular}{|l|rr|}
\hline $\begin{array}{l}\text { Restart Plan for the Prototype Vertical } \\
\text { Denitration Calciner }\end{array}$ & Huly 21, 1999 & HNF-4728, Revision 2 \\
\hline
\end{tabular}

\begin{tabular}{|c|c|c|c|}
\hline 13 & $\begin{array}{l}\text { Operations and off shift emergency } \\
\text { support is adequate. }\end{array}$ & $\begin{array}{l}\text { Provide list of needs and document verification } \\
\text { process. }\end{array}$ & COG ENG \\
\hline 14 & $\begin{array}{l}\text { All surrogate material runs are complete, } \\
\text { and the results satisfactory. The movement } \\
\text { to the next phase is recommended }\end{array}$ & $\begin{array}{l}\text { The checklist items for the next phase have been } \\
\text { reviewed for adequacy and completeness. }\end{array}$ & PPSL Mgr. \\
\hline $\begin{array}{l}\text { Hold } \\
\text { Point } \\
\# 3\end{array}$ & $\begin{array}{l}\text { All surrogate material runs have been } \\
\text { successfully completed, and the Manager, } \\
\text { PPSL has recommended the } \\
\text { commencement of fissile material activities } \\
\text { under the restart plan. }\end{array}$ & $\begin{array}{l}\text { Verify that the documents supporting the } \\
\text { completion of surrogate material runs, procedural } \\
\text { changes, etc have been completed, and the } \\
\text { process is ready to proceed to the next phase. }\end{array}$ & $\overline{\text { F.R.Crawford }}$ \\
\hline \multicolumn{4}{|c|}{ READINESS TO PROCEED TO UNRESTRICTED OPERATIONS CHECKLIST } \\
\hline 1 & $\begin{array}{l}\text { Procedures are adequate and correct. } \\
\text { Modifications from changes are } \\
\text { incorporated. }\end{array}$ & $\begin{array}{l}\text { Provide list of applicable procedures and } \\
\text { verification process used. }\end{array}$ & COG ENG \\
\hline 2 & $\begin{array}{l}\text { Level of knowledge is adequate to move } \\
\text { to the next phase. }\end{array}$ & Provide documentation of verification process & COG ENG \\
\hline 3 & $\begin{array}{l}\text { Spare parts and preventive maintenance } \\
\text { are adequate to move to the next phase. }\end{array}$ & $\begin{array}{l}\text { Provide list of parts/PMs and verification of } \\
\text { process used. }\end{array}$ & COG ENG \\
\hline 4 & $\begin{array}{l}\text { Safeguards and security requirements have } \\
\text { been addressed for the next phase. }\end{array}$ & $\begin{array}{l}\text { Provide documentation of verification process } \\
\text { used. }\end{array}$ & COG ENG \\
\hline 5 & $\begin{array}{l}\text { Radiological controls/equipment are } \\
\text { adequate to move to the next phase. }\end{array}$ & $\begin{array}{l}\text { Provide documentation of verification process } \\
\text { used. }\end{array}$ & COG ENG \\
\hline
\end{tabular}




\begin{tabular}{|c|c|c|c|}
\hline \multicolumn{2}{|c|}{$\begin{array}{l}\text { Restart Plan for the Prototype Vertical } \\
\text { Denitration Calciner }\end{array}$} & $\begin{array}{r}\text { HNF-4728, Revision } 2 \\
\text { Page } 18 \text { of } 19 \\
\end{array}$ & \\
\hline 6 & Criticality systems are operational. & $\begin{array}{l}\text { Provide documentation of verification process } \\
\text { used. }\end{array}$ & COG ENG \\
\hline 7 & $\begin{array}{l}\text { Seismic detection and shutdown systems } \\
\text { are tested and are operational. }\end{array}$ & $\begin{array}{l}\text { Provide documentation of verification process } \\
\text { used. }\end{array}$ & COG ENG \\
\hline 8 & $\begin{array}{l}\text { Verification that glovebox conditions meet } \\
\text { the CPS requirements for planned } \\
\text { operations. }\end{array}$ & $\begin{array}{l}\text { Provide documentation of verification process } \\
\text { used. }\end{array}$ & COG ENG \\
\hline 9 & Instrumentation is calibrated. & $\begin{array}{l}\text { Provide documentation of verification process } \\
\text { used. }\end{array}$ & COG ENG \\
\hline 10 & $\begin{array}{l}\text { Equipment repairs/modifications are } \\
\text { complete. }\end{array}$ & $\begin{array}{l}\text { Provide list of any repairs/modifications and } \\
\text { provide documentation of verification. }\end{array}$ & COG ENG \\
\hline 11 & $\begin{array}{l}\text { Training and qualifications are complete } \\
\text { and current. }\end{array}$ & $\begin{array}{l}\text { Provide documentation of verification process } \\
\text { used. }\end{array}$ & COG ENG \\
\hline 12 & Required corrective actions are complete. & $\begin{array}{l}\text { Provide list of corrective actions and } \\
\text { documentation of verification process. }\end{array}$ & COG ENG \\
\hline 13 & $\begin{array}{l}\text { Operations and off shift emergency } \\
\text { support is adequate. }\end{array}$ & $\begin{array}{l}\text { Provide list of needs and document verification } \\
\text { process. }\end{array}$ & COG ENG \\
\hline
\end{tabular}




\begin{tabular}{|l|lr|}
\hline $\begin{array}{l}\text { Restart Plan for the Prototype Vertical } \\
\text { Denitration Calciner }\end{array}$ & HNF-4728, Revision 2 \\
Page 19 of 19 21,1999 & \\
\hline
\end{tabular}

\begin{tabular}{|c|c|c|c|}
\hline 14 & $\begin{array}{l}\text { All fissile material runs under the restart } \\
\text { plan are complete, and the results } \\
\text { satisfactory. The movement to the next } \\
\text { phase is recommended }\end{array}$ & $\begin{array}{l}\text { The checklist items for the next phase have been } \\
\text { reviewed for adequacy and completeness. }\end{array}$ & PPSL Mgr. \\
\hline $\begin{array}{l}\text { Hold } \\
\text { Point } \\
\# 4\end{array}$ & $\begin{array}{l}\text { All fissile material runs conducted under } \\
\text { the restart plan have been successfully } \\
\text { completed, and the Manager, PPSL has } \\
\text { recommended the commencement of } \\
\text { unrestricted fissile material activities. }\end{array}$ & $\begin{array}{l}\text { Verify that the documents supporting the } \\
\text { completion of fissile material runs, procedural } \\
\text { changes, etc have been completed, and the } \\
\text { process is ready to proceed to unrestricted fissile } \\
\text { material activities. }\end{array}$ & $\overline{\text { F.R.Crawford }}$ \\
\hline
\end{tabular}

